\author{
I.A. Anashkina, I.I. Konkova \\ Ogarev Mordovia State University, \\ Saransk, Republic of Mordovia, \\ Russian Federation
} Получена: 09.08.2019

Принята: 24.09.2019

Опубликована: 09.01.2020

\title{
ONYMS IN ENGLISH SCIENTIFIC AND TECHNICAL DISCOURSE
}

\begin{abstract}
The article is devoted to the analysis of the onym functional characteristics in English scientific and technical discourse. The analysis is made on the material of scientific articles and monographs written by the native speakers or the scientists who use the English language as the foreign one. The Internet articles devoted to some scientists, inventions and discoveries are examined. All the studied onyms are divided into three groups: anthroponyms, eponyms and toponyms. There is a special classification for each onym according to the structure followed by the examples from the texts of scientific and technical discourse. The classifications proposed by the scholars are taken as a basis and modified according to the analyzed type of the discourse. The functions performed individually by the onym (anthroponym, eponym or toponym) are singled out as well as the functions performed jointly by all the studied onyms. Among the first ones there are internal conventionality of article/monograph, ethiquettical, discursive, attention attraction, memorial and indexal. Among the last ones there are recongnitive, axiological, authorship priority recognition and information compression functions. All the functions are presented in the Table. The conclusions of onym frequency use in the axiological function are made. The most prevalent function is marked out. The support to the following conclusions is provided.
\end{abstract}

Ключевые слова: onym, anthroponym, eponym, toponym, function, scientific and technical discourse.

\section{И.А. Анашкина, И.И. Конькова}

Мордовский государственный университет

им. Н.П. Огарева,

Саранск, Республика Мордовия,

Российская Федерация
Received: 09.08.2019

Accepted: 24.09.2019

Published: 09.01.2020

\section{ОНИМЫ В АНГЛОЯЗЫЧНОМ НАУЧНО-ТЕХНИЧЕСКОМ ДИСКУРСЕ}

Дан анализ функциональных особенностей онимов в англоязычном научно-техническом дискурсе. Материалом исследования выступают научные статьи и монографии, написанные как носителями английского языка, так и учеными, для кого данный язык является иностранным. Также были проанализированы интернет-статьи, посвященные ученым, открытиям и изобретениям. Рассматриваемые онимы поделены на три группы: антропонимы, эпонимы, топонимы. В каждой группе приведена классификация по структуре. За основу были взяты классификации, предложенные другими учеными. Они были адаптированы под исследуемый тип дискурса. Выделены функции, выполняемые каждым онимом индивидуально, а также предложена сводная таблица и подчеркнуты общие для всех онимов функции в англоязычном научно-техническом дискурсе. К первым отнесены функция внешней конфенциональности статьи/монографии, этикетная, дискурсивная, функция привлечения внимания, мемориальная и индексальная. К последним отнесены: рекогнитивная функция, функция признания приоритета авторства, функция компрессии информации и аксиологическая функция. Сделаны выводы о частотности употребления обозначенных онимов в аксиологической функции. Определена самая распространенная функция. Приведены обоснования указанного статистического вывода.

Keywords: оним, антропоним, эпоним, топоним, функция, научно-технический дискурс. 


\section{Introduction}

This article is based on the analysis of scientific and technical discourse. When the author creates texts belonging to this genre of discourse, he/she supposes that the reader is a specialist as well as the author him- or herself, and the reader has the same level of knowledge. The language material is presented by articles and monographs thematically devoted to nanotechnologies and fiber optic technology. The articles were published in the period of 1997-2015 in the periodicals like Optical Fiber Technology, Nano Research, Small, Nano Letters. The monographs are "Introduction to nanotechnology: The new science of small" [1] and "Fiber Optics. Physics and Technology [2]. The total material studied amounts to 1400 pages. Besides, there were 89 Internet articles devoted to some scientists, inventions and discoveries. These help build up the cultural and scientific background of the research. They also provide a detailed evaluation of onyms: anthroponyms, eponyms and toponyms. 1250 discursive passages containing onyms were picked out in the course of the continuous sampling method.

\section{The analysis of onyms and its results}

Anthroponyms constitute a large group of lexemes in any language including English. They represent the category of the person in different discourse types. All the texts of scientific and technical discourses are characterized with anthropocentricity. Anthroponymic lexis plays a special role in it. The aim of the author of a scientific text is not only to provide the reader with information and create certain conditions for its understanding but also to persuade the reader that this information is correct.

Anthroponyms are studied in anthropomy (from Greek "anthropos" - man and "onyma" - name) that is a branch of onomastics dealing with anthroponyms, their etymology, development and functioning [3, p. 66]. The following classification of anthroponyms has been proposed by T.V. Myaskovskaya and V.V. Semina: personal name, patronymic name, surname, nickname, pseudonym, cryptonym, anthroponyms formed from ethnicons [4, p. 52]. Nevertheless, not all these types are used in discourse. This fact can be explained by its chastity and officiality. In the material analyzed the following structures were discovered:

- name: Aeschylus [2, p. 3];

- surname: Namihira [5, p. 172];

- initials+surname: J.F. Mergen [6, p. 17];

- name+surname: Anish Priyadarsi [7, p. 183];

- name+numeral: Napoleon I [2, p. 4];

- name+middle name+surname: Idelfonso Tafur Monroy [8, p. 144];

- position (degree)+name (initials)+surname: Professor P. Khastgir [9, p. 296]. 
Eponimy is one more widely spread phenomenon in English scientific and technical discourse. According to E.V. Varnavskaya, eponimy is a nomination of things and events after real and mythic characters widely used in the names of geographic features, rewards, film companies and industrial groups [10, p. 9]. In the discourse under study such a nomination is related to inventions, laws, functions and other things named after scientists. D. Minkova and R. Stockwell gave the following definition of eponyms: "These are new words based on names (epi- "upon", onym "name") [11, p. 19]. In this article, an eponym is considered to be a structure composed of a proper name and a term (Anthr. $+\mathrm{N}$ (Noun)).

In this case an eponym denotes various scientific laws and substances. This structure has found its reflection in the following models:

- N (Noun): X-ray [2, p. 68];

- Anthr.+N (Anthroponym+Noun): the Morse alphabet [2, p. 3];

- Anrth.+Anthr. $+\mathrm{N}$ (Anthroponym+Anthroponym+Noun): Fabry-Perot filters [12, p. 35];

- Anthr.suf.+N (Anthroponym+suffix+Noun): Gaussian pulses [2, p. 58];

- Anthr.'s $+\mathrm{N}$ (Anthroponym in possessive case): Maxwell's equations [2, p. 25];

- eponyms-units of measure: $G H z$ [12, p. 116];

- eponyms-abbreviations: nonlinear Schrödinger (NLS) equation [12, p. 111].

The last type of onyms widely spread in English scientific and technical discourse is toponym. Toponymics (Greek topos- "place, country" + onyma- "name") is a linguistic discipline located at the boardelines of linguistics, geography and history. Toponymics is a branch of onomastics which deals with proper names [13, p. 3]. There are a lot of scholars (A.V. Superanskaya, L.V. Uspenski, R. Coats, M. Gelling, C. Smith) who are working in this sphere. As for classifications of toponyms, there are plenty of them. We have analyzed the most appropriate ones for the needs of this research. The first classification correlates with the morphologic structure [14], the second one is based on the type of the denoted geographic features [13].

O.A. Leonovich divided toponyms, according to the morphologic structure, into four groups [14, p.66]:

- simple toponyms (one base morpheme): France [2, p. 3];

- secondary toponyms (one base morpheme+suffix): Thuringian and Bavarian Forest [2, p. 87];

- complex toponyms (two base morphemes): the Netherlands [15, p. 3153];

- composite toponyms (two and more words): United States [16, p. 3159].

A.V. Superanskaya divided all toponyms into [13]:

- hydronyms (water object names): the Union Canal [2, p. 178];

- oronyms (mountain names): the Erzgebirge [2, p. 87];

- placenames (cities names): Sydney [17, p. 91];

- urbanonyms (intra-city object names): Deer Creek Road [18, p. 122]; 
- macrotoponyms (the names of big geographic features such as countries and so on): Asia-Pacific Region [6, p. 16];

- microtoponyms (small undeveloped lands): the Bavarian Forest [2, p. 88].

All the onyms mentioned above perform certain functions in English scientific and technical discourse. All of them are shown in Table.

Functions of onyms in English scientific and technical discourse

\begin{tabular}{|l|c|c|c|}
\hline Function & Anthroponym & Eponym & Toponym \\
\hline Internal conventionality of article/monograph & + & & \\
\hline Recognitive & + & + & + \\
\hline Axiological & + & + & + \\
\hline Ethiquettical & + & & + \\
\hline Discursive & + & & \\
\hline Attention attraction & + & & \\
\hline Authorship priority recognition & + & + & + \\
\hline Information compression & & + & + \\
\hline Memorial & & & + \\
\hline Indexal & + & + & + \\
\hline
\end{tabular}

As it can be seen from Table 1, onyms perform different functions but there are only four that are fulfilled by all of them: recognitive, authorship priority, information compression and axiological functions.

\section{Recognitive function}

(1) B. PRASAD was born in Varanasi, U.P., India on January 30, 1943 [9, p. 298]. The anthroponymic structure "initials+surname" contains information only about the author of this article without any reference. The initials are used for identification of the right person in case there is a namesake.

(2) To determine the peak positions more precisely, the diffraction pattern was fitted with a linear combination of Gaussian and Lorentzian line shapes with a 75-25\% ratio [19, p. 4916]. There are two eponymic structures "Anthr.suf+N" in this example. Each of them denotes the shape of a special line and have an "N" component in common. The difference makes the anthroponymic component. "Gaussian line shape" was named after the German mathematician, mechanic and physicist Carl Friedrich Gauss and "Lorentzian line shape" got its name after the Dutch physicist Hedrick Lorenz.

(3) Dr. Vaidyanathan Kripesh carried out his doctoral degree at Max Planc Institute for Metalforschung, Stuttgart, Germany, in area of microelectronics [7, p. 183]. There is some extra information about the author of this article. The institute he got his doctor's degree from is mentioned. The macrotoponym (Germany) and placename (Stuttgart) denote the location of the institute. 


\section{Function of authorship priority recognition}

(4) A graphic example of this idea is provided by the "one-time pad" cipher system proposed by Vernam in 1926 [20, p. 347]. The anthroponymic structure here consists of a "surname". Symmetric encryption (Vernam Cipher) is mentioned in this example. The author of this article states that his theory is based on the one proposed by Gilbert Vernam. The last one is considered as its founder.

(5) Rather, the motion of sMNP appears as a biased diffusion toward the magnetic tip, resulting from the superposition of Brownian motion with a magnetic drift... [21, p. 3487]. The eponymic structure is "Anthr.suf $+\mathrm{N}$ ". This phenomenon is widely known in physics as it is a proof of the molecular-kinetic theory about the random thermal motion of atoms and molecules. "Brownian motion" is named after the Scottish botanist Robert Brown. There were more accurate discoveries made by Lui George Gui. Nevertheless, the phenomenon got its name after the founder.

(6) Centre for Communication Networks Research, Department of Electrical and Electronic Engineering, Faculty of Science and Engineering, The Manchester Metropolian University, Chester Street, Manchester M15GD, United Kingdom [22, p. 247]. The information provided in this example is given in the beginning of the article right after the author's name. In other words, all the scientific discoveries made by the researcher belong not only to him but also to the university where they took place. The full postal address consisting of an urbanonim, a placename and a macrotoponym is given.

\section{Information compression function}

(7) Corwin et al. [26, 41$]$ identified the amplification of a quantum-limited shot noise and spontaneous Raman scattering as the main sources of for amplitude fluctuations in microstructure fiber?

26 - Corwin K.L., Newbury N.R., Dudley J.M., Coen S. et al. Fundamental noise limitations to supercontinuum generation in microstructure fiber. 2003

41 - Corwin K.L., Newbury N.R., Dudley J.M. et al. Fundamental amplitude noise limitations to supercontinuum spectra generated in microstructure fiber. 2003 [23, p. 131].

There is a three-component anthroponym used in this example. Both of them have a reference. If an article is written by more than one author, and when it is referred to in other scientific researches, only one name is used (generally the name of the scientist who has made the most essential contribution to the study). The rest of the authors is put in the references in the end of the article. This anthroponymic intrusion into the text of the article provides information compression.

(8) The EMTY model is based on an exponential expansion for the Jones matrix to obtain the individual and independent matrices for different PMD orders. Here we use the same name as that in for this model, which goes back to the initials of the authors surnames Eyal-Marshall-Tur-Yariv [24, p. 104]. 
This example has a reference to the article published in the scientific journal Electronic Letters in 1999 by A. Eyal, W.K. Marshall, M. Turn and A. Yariv. Its name is "Representation of second-order polarization mode dispersion". The scientists made a sample based on the expansion of the Jones matrix. The name of the sample is an abbreviation of its creators' names. This example is not typical because the abbreviation is written in full as well as a detailed explanation of its etymology is provided.

(9) While still in its infancy, the field of crystalline semiconductor core optical fibers has generated growing attention globally with the pioneering work principally from the United States and Europe. In addition to our work at Clemson University (US), important contributions have originated from a collaboration between the Pennsylvania State University (US) and Southampton University (UK) ... [25, p. 399]. There are several macrotoponyms in this example. The authors describe the creation and application of crystalline semiconductor core optical fibers. The first researches in this sphere took place in the USA and Europe. Later it was collaborative work of some American and European scientists. We can state that information compression function is realized here. The short names of the countries are supplied after the names of the universities.

The authors' special attention was paid to the axiological function of onyms in English scientific and technical discourse.

The problem of value has always been debateful. The anthropologic tendencies provide the rising tide of interest to the evaluation category [26]. The interest to axiology in the foreign linguistics distinguishes itself by constancy whereas, in contrast, in Russian linguistics this tradition was interrupted and got its amount of attention only quite recently (in the end of 1980s). The concept "value" is among the major ones in philosophy. It is considered as an essential aspect of gnoseology and research study methodology. V.V. Grechanyi who examined the philosophical aspect of this category noted that, broadly speaking, the concept "value" is equal to the concept "significancy" in its pragmatic meaning. Value denotes subjective properties of a phenomenon [27].

The above-mentioned anthroponymic structures within scientific and technical discourse have been analyzed from the point of view of their axiological function. All the passages containing evaluation are underlined.

(10) In hindsight, the paper by Kao and Hockham came out at just the right time. Very quickly tremendous progress in this direction was achieved in Japan, England, and the USA [2, p. 6]. Three macrotoponyms are used in this example. Kao and Hockham (Standart telecommunication laboratory in London) published an article in which they predicted a gradient fiber creation soon. They were not mistaken and soon after that this fiber type started being widely used in Japan, England and the USA. This fiber application in the mentioned above countries is described as "very quickly tremendous progress". The author estimates the fast development in the gradient fiber field. He also underlines the essential achievements in this sphere. 


\section{Conclusions}

The following conclusions have been made after the functional analysis of onyms in English scientific and technical discourse:

1. All onyms (anthroponyms, eponyms, toponyms) can be classified according to their functions.

As it can be seen from the Fig. 1, recognitive function prevails. In case of anthroponyms, this function helps differentiate scientists who are relatives having the same surname. Scientific dynasties are quite frequent that is why the appearance of similar surnames is inevitable. As for the namesakes, the list of surnames is restricted so it is unavoidable for them to reduplicate. Eponyms name scientific processes and phenomena using special lexical units which are finite. Moreover, researches can be done not only in completely new spheres but also in partially studied ones. Hence, there is an overlap of some name components which have to be distinguished. Toponyms provide concretization of a discovery and a research place that guarantee authorship priority compliance.
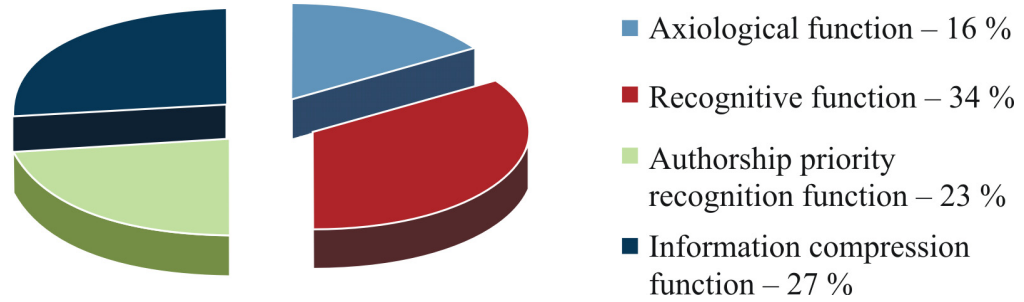

Fig. 1. The ratio of onyms in four functions

2. The author's evaluation can be tracked in various discourse types as well as in scientific-technical one which is considered to be official and precisely organized.

3. Lexical-grammatical means are perfect for evaluation expression. Such means are used together with the studied onyms such as anthroponyms, eponyms and toponyms.

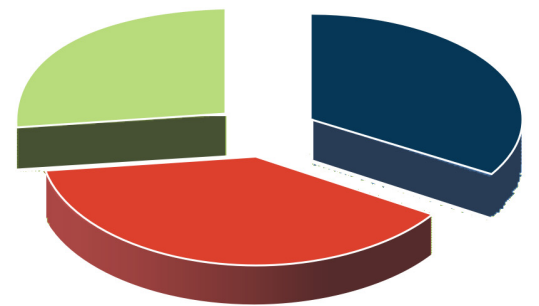

- Anthroponyms - $34 \%$

- Eponyms - $39 \%$

- Toponyms $-27 \%$

Fig. 2. The ratio of onyms in axiological function 
4. As it can be seen from Fig. 2, the axiological function is expressed by the onyms with almost equal frequency. Nevertheless, toponyms seldom act as such. This can be explained by the fact that evaluation is usually given to some scientific discovery or some work done by a scientist or a team. The assessment of the later invention territorial use by means of toponyms is rarely made.

\section{Список литературы}

1. Kelley S., Sargent T. Introduction to Nanotechnology: The New Science of Small. The USA: The Great Courses, 2012. - 172 p.

2. Mitschke F. Fiber Optics. Physics and Technology. - Berlin: Springer, 2009. - 301 p.

3. Подольская Н.В. Словарь русской ономастической терминологии. - М., 1978. - $201 \mathrm{c}$.

4. Мясковская Т.В., Семина В.В. Особенности классификации исторических антропонимов // Science and world. International scientific journal. - Volgograd, 2014. № 12 (16). - Vol. II. - P. 52-55.

5. Dispersion Compensating Fibers / L. Gruner-Nielsen [et al.] // Optical Fiber Technology. - 2000. - № 6. - P. 164-180.

6. Beaufils J.M. How do submarine networks web the world? // Optical Fiber Technology. - 2000. - № 6 (1). - P. 15-32.

7. Fiber misalignment in silicon V-groove based optical modules / A. Priyadarshi [et al.] // Optical fiber technology. - 2006. - № 12(2). - P. 170-184.

8. Coherent spectral amplitude coded label detection for DQPSK payload signals in packet-switched metropolitan area networks / A.V. Osadchiy [et al.] // Optical fiber technology. - Elsevier, 2011. - № 17. - P. 141-144.

9. Singh V., Prasad B., Ojha S.P. Weak guidance modal analysis and dispersion curves of an infrared lightguide having a core cross section with a new type of asymmetric loop boundary // Optical fiber technology. - Elsevier, 2000. - № 6. - P. 290-298.

10. Варнавская Е.В. Статус и функционирование эпонимов в медицинской терминологии испанского языка: автореф. дис. ... канд. филол. наук. - Воронеж, 2009. -24 c.

11. Minkova D., Stockwell R. English Words. History and Structure. - New York: Cambridge University Press, 2009. - 219 p.

12. Hirooka T., Wabnitz S. Nonlinear Gain Control of Dispersion-Managed Soliton Amplitude and Collisions // Optical Fiber Technology. - 2000. - № 6. - P. 109-121.

13. Суперанская А.В. Что такое топонимика? - М.: Наука, 1984. - 182 с.

14. Леонович О.А. В мире английских имен. - М.: АСТ, 2002. - 160 с.

15. Detection of individual proteins bound along DNA using solid-state nanopores / C. Plesa [et al.]. - Nano Letters. - 2015. - № 15. - P. 3153-3158.

16. Quenched phonon drag in silicon nanowires reveals significant effect in the bulk at room temperature / J. Sadhu [et al.]. - Nano Letters. - 2015. - № 15. - P. 3159-3165.

17. Minasian R.A. Photonic signal processing of high-speed signals using fiber gratings // Optical Fiber Technology. - 2000. - № 6. - P. 91-108. 
18. Baney D.M., Gallion P., Tucker R.S. Theory and measurement techniques for the noise figure of optical amplifiers // Optical Fiber Technology. - 2000. - № 6. - P. 122-154.

19. Self-Assembly of Ferromagnetic Organic-Inorganic Perovskite-Like Films / N. Akhtar [et al.] - Small. - 2014. - № 23. - P. 4912-4919.

20. Townsend P.D. Quantum Cryptography on optical fiber networks // Optical Fiber Technology. - 1998. - № 4. - P. 345-370.

21. Magnetogenetic control of protein gradients inside living cells with high spatial and temporal resolution / F. Etoc, C. Vicario [et al.]. - Nano Letters. - 2015. P. 3487-3794.

22. Murtaza G., Senior J.M. Analytical approach for optical crosstalk in LED-Sources WDM Systems // Optical Fiber Technology. - 1997. - № 3. - P. 247-251.

23. Optical spectral broadening and supercontinuum generation in telecom applications / S.V. Smirnov [et al.] // Optical Fiber Technology. - 2006. - № 12. - P. 122-147.

24. Xie C., Möller L. The accuracy assessment of different polarization mode dispersion models // Optical Fiber Technology. - 2006. - № 12. - P. 101-109.

25. Advancements in semiconductor core optical fiber / J. Ballato [et al.] // Optical Fiber Technology. - 2000. - № 16. - Р. 399-408.

26. Анашкина И.А. Язык и культура. Культурно-аксиологический подход. М.: Изд-во Моск. пед. гос. ун-та им. В.И. Ленина, 1994. - 120 с.

27. Гречаный В.В. Аксиологический аспект философии: дис. ... д-ра филос. наук. - Л., 1989. - 413 с.

\section{References}

1. Kelley S., Sargent T. Introduction to Nanotechnology: The New Science of Small. The USA, The Great Courses, 2012, 172 p.

2. Mitschke F. Fiber Optics. Physics and Technology. Berlin, Springer, 2009, 301 p.

3. Podol'skaia N.V. Slovar' russkoi onomasticheskoi terminologii [The Dictionary of Russian onomastic terminology. Moscow, 1978, $201 \mathrm{p}$.

4. Miaskovskaia T.V., Semina V.V. Osobennosti klassifikatsii istoricheskikh antroponimov [Features of historical anthroponyms classification]. Science and world. International scientific journal, 2014, no. 12(16), vol. II, pp. 52-55.

5. Gruner-Nielsen L. [et al.]. Dispersion Compensating Fibers. Optical Fiber Technology, 2000, no. 6, pp. 164-180.

6. Beaufils J.M. How do submarine networks web the world? Optical Fiber Technology, 2000, no. 6(1), pp. 15-32.

7. Priyadarshi A. [et al.]. Fiber misalignment in silicon V-groove based optical modules. Optical Fiber Technology, 2006, no. 12(2), pp. 170-184.

8. Osadchiy A.V. [et al.]. Coherent spectral amplitude coded label detection for DQPSK payload signals in packet-switched metropolitan area networks. Optical Fiber Technology, 2011, no. 17, pp. 141-144.

9. Singh V., Prasad B., Ojha S.P. Weak guidance modal analysis and dispersion curves of an infrared lightguide having a core cross section with a new type of asymmetric loop boundary. Optical Fiber Technology, 2000, no. 6(3), pp. 290-298. 
10. Varnavskaia E.V. Status i funktsionirovanie eponimov v meditsinskoi terminologii ispanskogo iazyka [Status and functioning of eponyms in the medical terminology of the Spanish language]. Abstract of Ph.D. thesis. Voronezh, 2009, 24 p.

11. Minkova D., Stockwell R. English Words. History and Structure. New York, Cambridge University Press, 2009, 219 p.

12. Hirooka T., Wabnitz S. Nonlinear gain control of dispersion-managed soliton amplitude and collisions. Optical Fiber Technology, 2000, no. 6, pp. 109-121.

13. Superanskaia A.V. Chto takoe toponimika? [What is Toponymy?]. Moscow, Nauka, 1984, 182 p.

14. Leonovich O.A. V mire angliiskikh imen [In the world of English names]. Moscow, AST, 2002, $160 \mathrm{p}$.

15. Plesa C. [et al.] Detection of individual proteins bound along DNA using solidstate nanopores. Nano Letters, 2015, no. 15, pp. 3153-3158.

16. Sadhu J. [et al.]. Quenched phonon drag in silicon nanowires reveals significant effect in the bulk at room temperature. Nano Letters, 2015, no. 15, pp. 3159-3165.

17. Minasian R.A. Photonic signal processing of high-speed signals using fiber gratings. Optical Fiber Technology, 2000, no. 6, pp. 91-108.

18. Baney D.M., Gallion P., Tucker R.S. Theory and measurement techniques for the noise figure of optical amplifiers. Optical Fiber Technology, 2000, no. 6, pp. 122-154.

19. Akhtar N. [et al.]. Self-Assembly of ferromagnetic organic-inorganic perovskitelike films. Small, 2014, no. 23, pp. 4912-4919.

20. Townsend P.D. Quantum cryptography on optical fiber networks. Optical Fiber Technology, 1998, no. 4, pp. 345-370.

21. Etoc F., Vicario C. [et al.]. Magnetogenetic control of protein gradients inside living cells with high spatial and temporal resolution. Nano Letters, 2015, pp. 3487-3794.

22. Murtaza G., Senior J.M. Analytical approach for optical crosstalk in LEDSources WDM Systems. Optical Fiber Technology, 1997, no. 3, pp. 247-251.

23. Optical spectral broadening and supercontinuum generation in telecom applications. Smirnov S.V. [et al.]. Optical Fiber Technology, 2006, no. 12, pp. 122-147.

24. Xie C., Möller L. The accuracy assessment of different polarization mode dispersion models. Optical Fiber Technology, 2006, no. 12, pp. 101-109.

25. Ballato J. [et al.] Advancements in semiconductor core optical fiber. Optical Fiber Technology, 2000, no. 16, pp. 399-408.

26. Anashkina I.A. Iazyk i kul'tura. Kul'turno-aksiologicheskii podkhod [Language and culture. Cultural-axiological approach]. Moscow, Moscow Pedagogical State University, 1994, $120 \mathrm{p}$.

27. Grechanyi V.V. Aksiologicheskii aspekt filosofii [Axiological aspect of philosophy]. Doctor's degree dissertation. Leningrad, 1989, 413 p. 


\section{Сведения об авторах}

\section{АНАШКИНА Ирина Александровна}

e-mail:Iraida952@gmail.com

Доктор филологических наук, профессор кафедры английского языка для профессиональной коммуникации, Мордовский государственный университет им. Н.П. Огарева (Саранск, Российская Федерация)

\section{КОНЬКОВА Инна Игоревна}

e-mail:mirna_13@mail.ru

Кандидат филологических наук, старший преподаватель кафедры английского языка для профессиональной коммуникации, Мордовский государственный университет им. Н.П. Огарева (Саранск, Российская Федерация)

\section{About the authors}

Irina A. ANASHKINA

e-mail: Iraida952@gmail.com

Doctor of Philology, Professor, Chair of English language for Professional Communication, Ogarev Mordovia State University (Saransk, Russian Federation)

\section{Inna I. KONKOVA}

e-mail:mirna_13@mail.ru

Candidate of Philological Sciences, Senior Lecturer, Chair of English Language For Professional Communication, Ogarev Mordovia State University (Saransk, Russian Federation) 